Disciplining Reproduction 



\section{Disciplining \\ Reproduction}

Modernity, American Life Sciences, and "the Problems of Sex"

Adele E. Clarke

UNIVERSITY OF CALIFORNIA PRESS

Berkeley Los Angeles London 


\section{University of California Press \\ Berkeley and Los Angeles, California \\ University of California Press, Ltd. \\ London, England}

(C) 1998 by the Regents of the University of California

Library of Congress Cataloging-in-Publication Data

\section{Clarke, Adele E.}

Disciplining reproduction : modernity, American life sciences, and "the problems of sex" / Adele E. Clarke.

p. $\mathrm{cm}$.

Includes bibliographic references and index

ISBN 0-520-20720-3 (alk. paper)

1. Reproduction-Research-United States-History-2oth century.

2. Reproductive technology-Social aspects. 3. Sex (Biology) - Research-United States-History-2oth century. 4. Life sciences-Research-United StatesHistory-2oth century. 5. Women-Health and hygiene. 6. Animal breeding. I. Title.

QP251.C56 1998

$612.6^{\prime} 07^{\prime} 2073$-dc 21

97-1114

Printed in the United States of America

$$
\begin{array}{lllllllll}
9 & 8 & 7 & 6 & 5 & 4 & 3 & 2 & 1
\end{array}
$$

The paper used in this publication meets the minimum requirements of American National Standard for Information Sciences-Permanence of Paper for Printed Library Materials, ANSI Z $39 \cdot 4^{8-1984}$. 
For Allan, without whom . . . 
